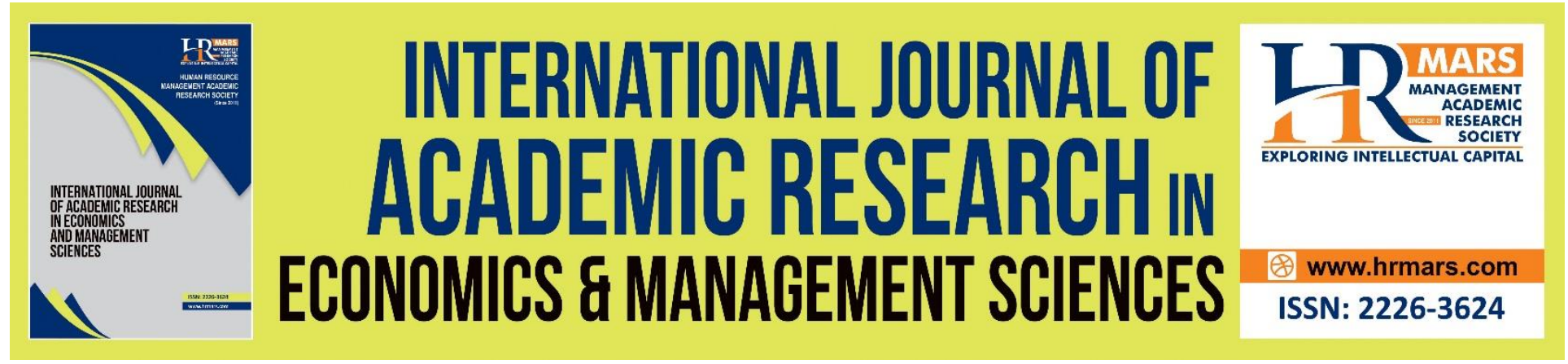

\title{
An Analysis of the Impact of Chinese Competition on Zimbabwe's Manufacturing Exports in Third Markets
}

Fanuel Hazvina

To Link this Article: http://dx.doi.org/10.6007/IJAREMS/v10-i1/9803

DOI:10.6007/IJAREMS/v10-i1/9803

Received: 26 January 2021, Revised: 24 February 2021, Accepted: 16 March 2021

Published Online: 29 March 2021

In-Text Citation: (Hazvina, 2021)

To Cite this Article: Hazvina, F. (2021). An Analysis of the Impact of Chinese Competition on Zimbabwe's Manufacturing Exports in Third Markets. International Journal of Academic Research in Economics and Managment and Sciences, 10(1), 202-221.

Copyright: @ 2021 The Author(s)

Published by Human Resource Management Academic Research Society (www.hrmars.com)

This article is published under the Creative Commons Attribution (CC BY 4.0) license. Anyone may reproduce, distribute, translate and create derivative works of this article (for both commercial and non-commercial purposes), subject to full attribution to the original publication and authors. The full terms of this license may be seen

at: http://creativecommons.org/licences/by/4.0/legalcode

Vol. 10, No. 1, 2021, Pg. 202 - 221

http://hrmars.com/index.php/pages/detail/IJAREMS

JOURNAL HOMEPAGE

Full Terms \& Conditions of access and use can be found at http://hrmars.com/index.php/pages/detail/publication-ethics 


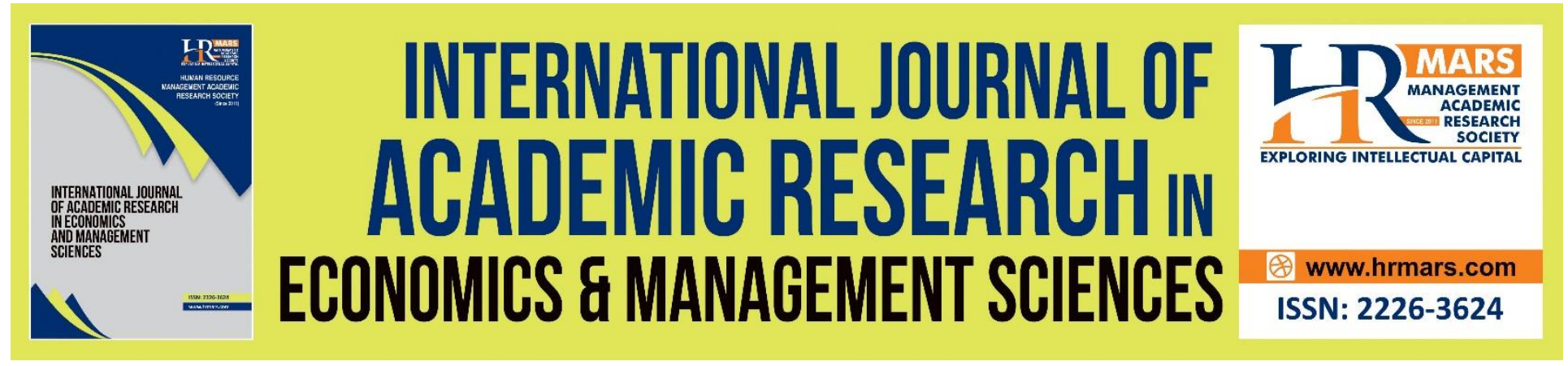

\title{
An Analysis of the Impact of Chinese Competition on Zimbabwe's Manufacturing Exports in Third Markets
}

\author{
Fanuel Hazvina \\ University of Zimbabwe, P.O. Box MP167, Mt. Pleasant Harare, Zimbabwe
}

\begin{abstract}
This study analyses the impact of Chinese competition on Zimbabwe's manufacturing exports in thirds markets using the Index of Competitive Threat (ICT) and the Constant Market Share (CMS) analysis. The ICT results reveals that competitive threat from China has increased between 2001 and in most of Zimbabwe's major African export markets. The CMS analysis findings reveals that Zimbabwe lost market share to China in export markets that include South Africa, Zambia, UAE and Mozambique. Zimbabwe marginally gained market share from China in Belgium, France and Malawi. The products greatly affected are mainly from the labour intensive sectors such as mining, agriculture, clothing and textiles and light manufacturing sectors. The study recommends that Zimbabwe move up the ladder in terms of export structure and upgrading its industry through value addition to enable its exports to compete at the highest level of that ladder. It should embark on qualitative upgrading of its exports as a way of offsetting at least part of the competitive pressure coming from China.

Keywords: Chinese Competition, Manufacturing Exports, Third Markets, Constant Market Share Analysis

\section{Introduction}

China has received enormous attention from both developed and developing countries since its economic boom in 1978. For developing countries, China presents both challenges and opportunities whilst developed countries view China as a threat to their world dominance. Developing countries are concerned with Chinese imports implications on employment, price level, innovation and crowding out products in both domestic and third markets (Giovannetti et al., 2010; Eichengreen; et al., 2004; Jenkins, 2012, Giovannetti \& Sanfilippo, 2009).
\end{abstract}

In addition to concerns on displacement of Sub Saharan Africa's local production in domestic markets, there have also been arguments that Chinese exports have crowded out other developing countries' exports in third markets (Jenkins \& Edwards, 2013; Geda \& Meskel, 2008). Findings from studies that have focussed on Africa have suggested that Chinese competition in 
third markets negatively affect exports of manufactured products from Africa. For example, Jenkins \& Edwards, (2006), Kaplinsky et al., n.d. and Giovannetti \& Sanfilippo (2009) identified a number of SSA countries whose exports were threatened by increased Chinese competition.

Zimbabwe has not been a stranger to the 'China phenomenon'. According to UN COMTRADE (2018), Zimbabwe has experienced a decline in the share of its exports to its major export markets both in the region and abroad. In contrast, China has increased its share of exports to most of these markets. This scenario raises questions on whether the displacement of Zimbabwe's exports from its traditional markets can be attributed to Chinese competition or to other factors such as product composition, product adaptation or competitive issues that may emanate from internal production bottlenecks.

Despite the increasing relations between Africa and China, there is still lack of empirical evidence that supports many of the key views about China's influence on many African countries, Zimbabwe included. According to Ajakaiye, (2006) and Lin \& Wang, (2014), most of the arguments relating to the impacts of China are based on press articles and therefore most of the information written on Africa-China trade relations is anecdotal, and often highly prejudicial. Furthermore, most literature that have focused on the impact of China on Africa in most cases is oriented towards win-lose findings, although many have not been rigor in terms of methodology (Ado et al., 2016). This study derives its motivation from the fact that most of the conclusions on the impact of Chinese competition on the African countries including Zimbabwe are neither evidence-based nor rigorous in their argumentation. It is also important to note that existing studies on the competitive effects of China on African countries' exports have used mainly aggregate data not product-level data. This study uses disaggregated data at 6-digit level, which helps in identifying and clearly explaining the competitive and complimentary effects of China's exports on specific products.

To the best of my knowledge, there has been no attempt to analyse the effects of Chinese competition on Zimbabwe's exports in third markets. Most work done on Zimbabwe- China trade relations have been done in the form of press articles that are either support the Look East Policy or those interested in discrediting the policy. Furthermore, most literature on Zimbabwe-China trade relations have only focussed on the direct effects of the relationship and ignored the indirect effects such as the impacts on Zimbabwe's exports in its major export markets. As a result, based on the available literature, it becomes difficult to conclude with confidence whether Chinese exports have negatively affected Zimbabwe's manufacturing sector exports or not. From this discussion, it is abundantly clear that there are significant knowledge-gaps, and unless these are filled, policy towards the country's engagement with China, other Asian countries and Western countries may continue to be misdirected. In light of these issues raised, this study found it important to carry out a detailed analysis on how Chinese exports have affected Zimbabwe's exports in third markets.

\section{Study Objectives}

The objectives of the study are to: 
- Determine if there is any competition between China and Zimbabwe in third export markets and if it exist the extent to which Chinese competition has led to the displacement of Zimbabwean exports in its major markets.

- Determine the countries in which Zimbabwean exports been most affected.

- Determine the Zimbabwean products that face the greatest threat from Chinese competition.

\section{Analysis of Zimbabwe's Trade}

During the period 2000 to 2016, Zimbabwe experienced subdued export performances and rising imports resulting in the country experiencing trade deficits in most years. During this period, exports increased by 134 percent from US\$1.2 billion in 2001 to US\$2.8 billion in 2016 whilst imports rose by 203 per cent from US\$1.7 billion to US\$5.2 billion (UN COMTRADE, 2018). Figure 1 shows Zimbabwe's trade performance between 2001 and 2016.

Figure 1: Zimbabwe's trade performance (2001-2016)

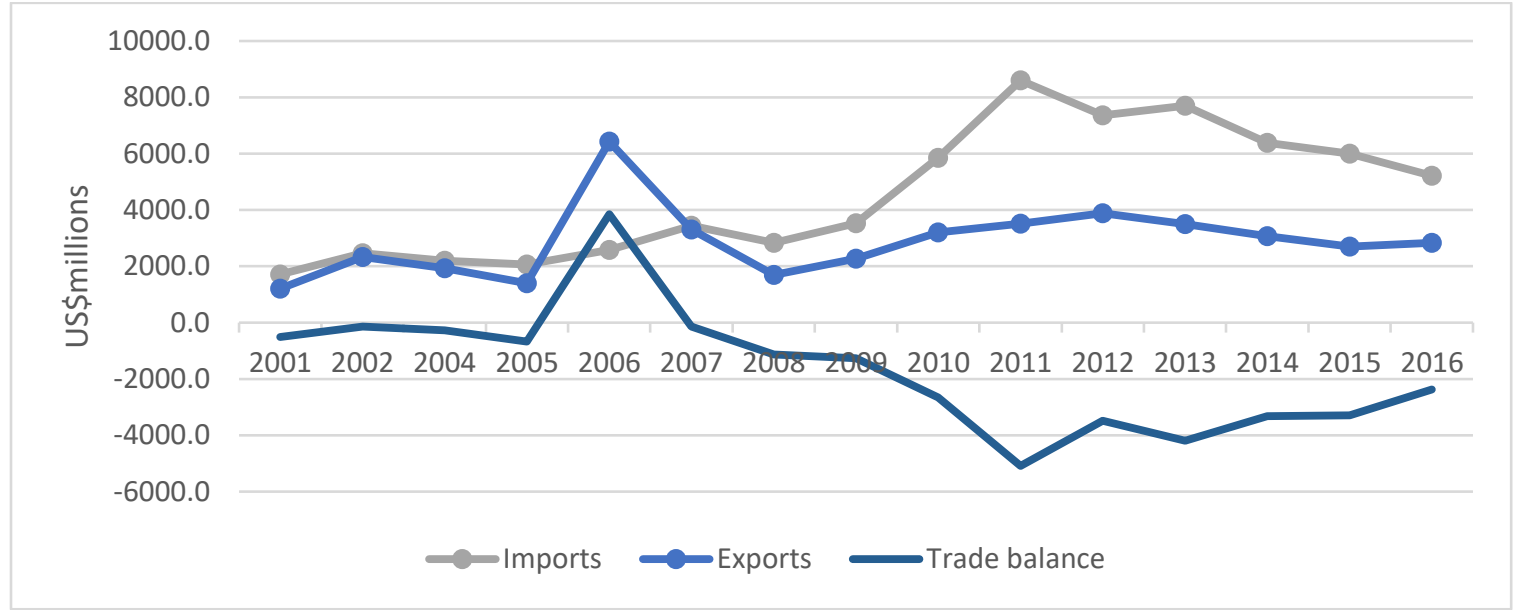

Data Source: Trademap Database

\section{Zimbabwe exports to its major markets}

Zimbabwe does not have diversified exports market destinations as close to $90 \%$ of its exports goes to two countries (South Africa and Mozambique). In 2016, 79.4\% of Zimbabwe's exports went to South Africa whilst Mozambique received 9.5\% of Zimbabwe's exports. The country's share of exports to European countries have been declining since 2000 whilst China did not feature among the top destination markets for Zimbabwe's products during the period under consideration. Table I shows Zimbabwe's major export markets and the share in value of the country's exports between 2000 and 2016. 
INTERNATIONAL JOURNAL OF ACADEMIC RESEARCH ECONOMICS AND MANAGEMENT SCIENCES Vol. 10, No. 1, 2021, E-ISSN: 2226-3624 @ 2021 HRMARS

Table I: Share in value in Zimbabwe's exports (\%) 2000-2016

\begin{tabular}{|c|c|c|c|c|c|c|c|c|c|c|c|c|c|c|c|}
\hline Importe & 20 & 20 & 20 & 20 & 20 & 20 & 20 & 20 & 20 & 20 & 20 & 20 & 20 & 20 & 20 \\
\hline & 10 & 10 & 10 & 10 & 10 & 10 & 10 & 10 & 10 & 10 & 10 & 10 & 10 & 10 & 10 \\
\hline World & 0 & 0 & 0 & 0 & 0 & 0 & 0 & 0 & 0 & 0 & 0 & 0 & 0 & 0 & 0 \\
\hline South & 10. & 18. & 29. & 41. & 17. & 37. & & 52. & 54. & 67. & 68. & 74. & & 71. & 79. \\
\hline Africa & 1 & 5 & 3 & 5 & 3 & 5 & 42 & 5 & 2 & 2 & 9 & 5 & 67 & 1 & 4 \\
\hline $\begin{array}{l}\text { Mozamb } \\
\text { ique }\end{array}$ & 0.3 & 3 & 1 & 2.8 & 5.7 & 13 & 2.4 & 4.3 & 2.9 & 3.7 & 7.3 & $\begin{array}{r}10 . \\
5\end{array}$ & $\begin{array}{r}18 . \\
8\end{array}$ & $\begin{array}{r}15 . \\
1\end{array}$ & 9.5 \\
\hline $\begin{array}{l}\text { United } \\
\text { Arab } \\
\text { Emirates }\end{array}$ & 0.3 & 0.4 & 0.6 & 0.7 & 0.4 & 0.7 & 0.6 & 0.8 & $\begin{array}{r}10 . \\
3\end{array}$ & 5.9 & $\begin{array}{r}12 . \\
4\end{array}$ & 6.5 & 3.1 & 5.5 & 4.1 \\
\hline Zambia & 1 & 9.3 & 3.7 & 5.6 & $\begin{array}{r}25 . \\
7\end{array}$ & 3.8 & 4.1 & 3.6 & 2.3 & 2.4 & 2.5 & 3.3 & 3.4 & 3.4 & 2.5 \\
\hline Belgium & 1.1 & 0.4 & 0.4 & 2.4 & 0.8 & 0.9 & 2.2 & 2.7 & 1.9 & 1.7 & 1.2 & 0.8 & 4.1 & 0.7 & 1.6 \\
\hline $\begin{array}{l}\text { Botswan } \\
\text { a }\end{array}$ & 1.1 & 2.9 & 2.5 & 2.1 & 4.5 & 6.1 & 9.3 & 1.6 & 0.9 & 1.1 & 1.3 & 1.3 & 0.9 & 1.1 & 1 \\
\hline Kenya & 0.3 & 0.6 & 0.2 & 0.1 & 0.1 & 0.9 & 0.3 & 0.1 & 0.6 & 0.1 & 0 & 0 & 0 & 0 & 0.4 \\
\hline France & 2.3 & 1.6 & 0.5 & 0.6 & 1.4 & 0.3 & 2 & 0.3 & 0.4 & 0.4 & 0 & 0 & 0.4 & 0 & 0.3 \\
\hline Namibia & 0.9 & 1.2 & 0.7 & 0.8 & 0.3 & 0.4 & 0.6 & 0.2 & 0.2 & 0.1 & 0 & 0.2 & 0.3 & 0.5 & 0.3 \\
\hline Malawi & 0.9 & 5.2 & 2.5 & 1.9 & 0.7 & 1.7 & 4.3 & 1.3 & 1.1 & 0.6 & 0.1 & 0.2 & 0.2 & 0.1 & 0.1 \\
\hline
\end{tabular}

Source: International Trade Centre database calculations based on UN COMTRADE statistics

\section{Chinese exports to Zimbabwe's major export destinations}

Since 2001, China's exports to African markets have increased. Figure 2 shows that China has increased its exports to markets which are also Zimbabwe's major export markets. China increased its share in South Africa's imports from around 4\% in 2001 to about $18 \%$ in 2016 . This means that if consumption in the South African market has not increased then possibly China will be eating into other countries' share and as a result other countries will likely see their exports to that market falling. It is interesting to note that in the markets where Zimbabwe's export share has been declining, China has managed to increase its market share in those markets. What this simply imply is that Chinese products have managed to penetrate into these markets at the expense of Zimbabwean products. 
Figure 2: Share of China's exports in the imports of Zimbabwe's major export destinations

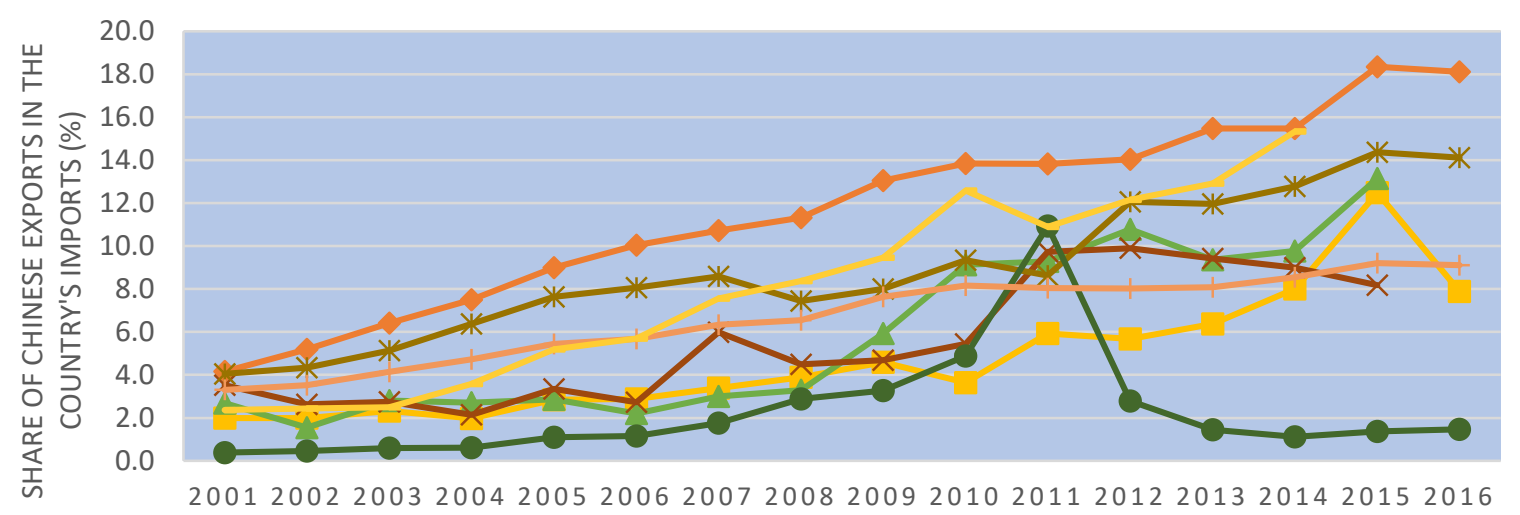

$\longrightarrow$ South Africa $\quad \longrightarrow$ Mozambique $\quad \longrightarrow$ Malawi $\quad \leftarrow$ Zambia

Source: International Trade Centre database calculations based on UN COMTRADE statistics

\section{Literature Review}

\section{Theoretical Literature Review}

The origins of the debate on relationship between trade and economic growth can be traced back to the classical economic theories by Adam Smith (1776) and David Ricardo (1817), Neo Classical trade theories of Heckscher and Ohlin (1933) and Prebisch, and Singer (1950). The early classical and neoclassical theories of trade view international trade as an engine for economic growth because of its effects on resource allocation. According to these theories, trade exposes countries to new technology and allows them to take advantage of economies of scale, which further lead to efficiency in production. On the other hand, Prebisch and Singer (1950) are of the view that developing countries are inadequately compensated for their natural resources through trade and this result in sluggish economic growth rates and increase in poverty levels.

This study is based on Armington (1969) model of international trade. The model postulates that commodities produced in different countries are considered to be different and consumers would prefer consuming at least some of each country's commodities. For example, within the Armington framework, Zimbabwean beef imported into South Africa is distinguished from beef that have been imported from China and the two products would represent two imperfectly substitutable products on the South African market. According to Benkovskis and Wörz (2014) the Armington model involves the decomposing changes in trade flows into two separate components. The first component is driven mainly by demand and the market shares are kept constant whilst the second component is largely based on price changes and therefore reflects the producer's competitiveness.

The Armington model contains two major assumptions induced by the constant elasticity of substitution (CES) sub utility function: the single CES and homotheticity assumptions. Under the single CES assumption, the elasticity of substitution between any two goods does not depend on the quantity demanded. In the Armington model, the single CES assumption restricts responses 
of the import demand for each product to the price change (relative to the price index for the good) to be the same for all products. This assumption would be too restrictive if elasticities of substitution between any pair of products are not the same. Even under the single CES circumstance, effects of relative price changes on market shares are not likely to be the same.

The homotheticity assumption in the Armington model implies that size of market does not affect each exporting country's relative market share, and that expenditure elasticities are the same and unitary. This assumption, though simplifying the model specification, may also be too restrictive for empirical research. If a good is differentiated so that each product gives different utility, an increase in the buyer's budget may not be allocated in the same proportion to all products. A relatively high proportion would be allocated to the high-quality or more preferred product given other factors remaining constant.

\section{Empirical Literature Review}

A number of studies have attempted to analyse the impact of China's export growth on other countries' exports in third markets. These include;(Ahearne, et al. 2003); Lall \& Albaladejo, (2004); Jenkins \& Edwards, (2006); Blazquez-Lidoy et al. (2006); Eichengreen; et al., (2004); Greenaway et al., (2008) ; Giovannetti \& Sanfilippo, (2009); and Jenkins \& Edwards, (2013)These studies have used various approaches which include the Computable General Equilibrium (CGE), Constant Market Share analysis (CMS), trade indices and econometric methods. These studies' findings have been inconclusive as they provided contrasting findings on the effects of Chinese exports on other countries' exports. Some of the studies concludes that China competes mainly with Asian countries, transition economies of Eastern Europe, Latin America and Africa whilst others found that competition from China is not a major threat to African exports.

The Computable General Equilibrium (CGE) setting have been widely used in analysisng the impact of Chinese exports in third markets. Yang and Tang (2000) used the GTAP model to examine the impact of China's growth over the period 1975-1995. The study found out that Newly Industrialized economies experienced export losses in third markets but these losses were offset by increased exports to China whilst for developing countries from other regions, competition in third markets outweighed the complementary demand effects from China. Similarly, lanchovichina and Martin (2001) concluded that the accession of China to the WTO resulted in relatively small losses for developing countries' exports of products in the textiles and apparel sectors in third markets. IMF (2004) estimated that China's rising shares in world output and trade are already having significant repercussions for most countries around the world. However, Blazquez-Lidoy et al (2006) did not find any displacement impacts by Chinese exports on Latin American countries except for Mexico which faced strong competition from China in third markets.

The Constant Market Share (CMS) analysis have also been used to analyse the impact of Chinese exports in third markets. Lall \& Albaladejo, (2004) assessed China's potential competitive threat in different markets in the 1990s by computing relative market shares and revealed market share losses in Korea, Taiwan, Singapore and Hong Kong and low market share gains in Malaysia, 
Thailand, Indonesia and Philippines. Husted \& Nishioka, (2013) found that during the period 1995 to 2010, Chinese export share growth was best explained by the market share effect. In another study that also used the CMS analysis, Sekakela, (2014) found out that Botswana lost market share to China in almost all TCF products in the South African market and the loss of market share actually increased over time.

The other group of studies explored changes in trade indices to assess the impact of Chinese exports in third markets. In a study that utilized export similarity indices for Malaysia, Thailand and Singapore (Li and Song, 2005) revealed increases in bilateral export similarities between China and Malaysia and between Thailand and Singapore between 1995 and 2003. This increase in the export similarities suggested that the countries' export structures were becoming similar thereby leading to greater competition in third markets. Hong Kong Monetary Authority (2002) used the revealed comparative advantage (RCA) measures to explore changes in competitiveness and comparative advantage in the NIES and the ASEAN-4 countries and found no evidence of displacement effect on the countries included in the study. Adams, et. al. (2004) computed a dynamic form of the RCA index for East Asian countries to capture China's changing competitiveness and found a general declining trend in RCAs of most East Asian countries since 1995. Qureshi \& Wan (2006) also found similar results in a study that examined the impact of China and India on each other and on the rest of the world using trade competition and complementarity indices. However, an important limitation of the study by Qureshi \& Wan (2006) is that it did not cover the services sector which is key for India.

Another approach that have been widely used to analyse the impact of Chinese exports on other countries is the econometric methodology. Studies by Ahearne et. al, (2003); Eichengreen; et al., (2004); Geda \& Meskel (2008); Razmi et al., (2006) have used the gravity model to examine the competitive effects of Chinese exports. Eichengreen; et al., (2004) showed that China crowded out less developed countries' exports of consumer goods in third markets. Similar results were found by Razmi et al., (2006) who found crowding effects by Asian countries on American markets although they varied across time periods, SITC categories and level of technological sophistication of exports. On the other hand, Jenkins \& Edwards (2006) did not find any evidence of competitive threat from China and India on Sub Saharan Africa except for Lesotho where its textile industry was affected. On the import front, their finding concurred with that of Stevens \& Kennan (2006) who concluded that a few SSA countries do not compete with China as most Chinese exports are those associated with a rapidly industrializing state and therefore a few SSA states fall in to this category. Schiere et al. (2011) confirmed the findings of crowding out effects by Stevens \& Kennan (2006); Geda \& Meskel, (2008); Giovannetti and Sanfilippo (2009) and Ademola et al. (2009). Eichengreen; et al. (2004) identified labour intensive consumer goods as among the casualties but could not find any evidence of displacement of exports of intermediate goods.

Based on the various literature reviewed, it is clear that definitive answers dealing with China's presence in Africa remain mostly controversial. The literature reviewed do not seem to be conclusive. The existing studies are subject to several shortcomings that include the data used that is often too aggregated. This study estimated the model using disaggregated data to analyse 
Chinese exports to Zimbabwe's major export destinations. This product level analysis can provide precise information on the products that are produced by Zimbabwe that competes with products from China. The problem of using aggregated data is that it will give false results because within a broadly defined product group (aggregated) there could be some products whose exports are growing whilst some will be declining and the overall effect will be determined by whether those with increasing exports are more than those with diminishing exports. Therefore, when products are narrowly defined, we will be able to identify displacement at the product and not the industry level.

\section{Methodology}

The Export Similarity Index (ESI) is the widely used index in analysing the Chinese competitive threats on other countries' exports in third markets. However, this uses the Index of Competitive Threat (ICT). The ICT captures both the extent and intensity of the competitive threat posed by China for Zimbabwe by weighting the share of each product in Zimbabwe's total exports. The ICT is given by:

$$
I C T=\sum X_{Z i} * k_{C i}
$$

Where: $X_{Z i}$ is the share of product $i$ in total imports from Zimbabwe by the destination market and $k_{C i}$ is China's share in total imports of product $i$ by the destination market.

The ICT ranges from zero to one, with a value of zero indicating that there is no similarity between the 2 countries' exports to the destination market. A value of one indicates that all of the two countries' exports to the destination market are similar. The ICT is expected to increase over time because of an increasing number of products that face Chinese competition and the rising Chinese penetration of existing product markets. One major strength of the ICT over the ESI is that an increase in a country's share in a particular market, ceteris paribus, leads to an increase in the index unlike the ESI where the index remains constant. However, the ICT has some problems in that it does not provide either a means of estimating the extent to which a country's exports have lost market share to the competitor country over the period under consideration or the products most affected.

This study complements the ICT with the CMS Analysis. This approach has been used in a number of studies that include(Chen and Duan (2001);Jenkins \& Edwards (2013). The CMS analysis decomposes the export performance into market share effect or competitiveness effect, commodity or product composition effect, and the relative commodity adaptation effect. The exposition used in this study is along the lines of Fagerberg \& Sollie (1987). Formally, the change in the market share can be expressed as:

$$
\Delta k_{B}=\Sigma \Delta k_{B i} * m_{A i}+\Sigma k_{B i} * \Delta m_{A i}+\Sigma \Delta k_{B i} * \Delta m_{A i}
$$

Where: $k_{B i}$ is the share of country B (Zimbabwe) in country A's (destination country) imports of product $i$, and $\Delta k_{B i}$ is the change in the total market share of export value from country $\mathrm{B}$ in the 
total import value of the trading partner (country A). $m_{A i}$ is the share of product $i$ in country A's total imports of all manufactured goods.

The first term ( $\Sigma \Delta k_{B i} * m_{A i}$ ) on the right hand side of equation (2) measures the competitiveness or market share effect. It captures the extent to which Zimbabwe or China's market share of a specific product has changed at the initial commodity composition of the imports in the trading partner. The competitiveness effect gives the aggregate impact of changes in market shares of each product in each destination market as a result of both price and non-price factors. The competitive effect is positive when a country enjoys a competitive advantage and negative for a competitive disadvantage.

The second term ( $\left.\Sigma k_{B i} * \Delta m_{A i}\right)$ measures the product or commodity composition effect. This defines the influence of the product specialisation on a country's exports. If a country specialises in products with a strongly growing foreign demand, then the product composition effect will be positive implying that the gain in the market share will be due to product specialisation only.

The third term $\left(\Sigma \Delta k_{B i} * \Delta m_{A i}\right)$ is the relative commodity adaptation effect or the market distribution effect. It reflects the extent to which a country has managed to adapt the commodity composition of its exports to changes in the commodity composition of the trading partner's imports relative to other exporting countries. It takes a value of zero, when the exporting country has adapted to the commodity composition at the same rate as other exporting countries. The commodity adaptation effect is positive when a country's exports are directed to markets where the demand is strongly growing and negative when the country's exports are directed to markets in which growth in demand is slower than the demand growth in the rest of the world.

After analysing the extent to which Zimbabwe faces competition from China in its major markets and the loss in market share attributed to the declining competiveness at the product level, it is important to look at the extent to which the loss in market share attributed to Chinese competition. To estimate this, the study uses an extension of Constant Market Share (CMS) analysis by Batista (2006). This helps in dividing a country's market share loss that attributed to the competitiveness effect to the different countries with which it competes in a given market. The assumption being that countries gain from those countries with exports growing more slowly and lose to those with exports growing faster than their own counterparts. Therefore, the loss of market share by Zimbabwe (Z) to China (C), in a particular product $i$ defined as:

$$
\Delta k_{Z C i}=\Delta k_{Z i} * k_{C i}^{t}-\Delta k_{C i} * k_{Z i}^{t}
$$

Where: $k_{Z i}^{t}$ and $k_{C i}^{t}$ are the shares of Zimbabwe and China respectively in destination country's imports of product $i$ in period t; and $\Delta k_{Z C i}$ is the change in market share by Zimbabwe to China in a particular product $i$;

Taking the sum over all products gives the aggregate loss of market share to China:

$$
\Delta k_{Z C}=\sum m_{A i}^{t} * \Delta k_{Z C i}
$$


Where $m_{A i}^{t}$ is the share of product $i$ in the destination country's total imports of all manufactured goods in base year $t$.

In a conventional Constant Market Share analysis, the sum of all exporters to the destination market gives the total competitiveness effect. It is important to note that a country cannot lose or gain from itself. A country's total gain or loss in market share is found by taking the sum of the gains and losses of any country to all its competitors.

In order to calculate the loss experienced by Zimbabwe to China in the destination market, we only need to know the shares of Zimbabwe and China in total imports of each product in the destination country at the beginning and at the end of the period under consideration. To calculate the loss in US\$ terms we need the total value of destination country's imports of each product.

\section{Data and Scope of Study}

Since this study is interested in the competition between Zimbabwe and China in each destination, it draws upon import data of each of the top 10 markets for Zimbabwe's exports. The study used 6-digit level of the Harmonized System (Revision 1996) data. The choice of highly disaggregated was motivated by the need to be able to do a proper comparison between same products rather than the case when the product classification is too broad. The study covered the period 2001 to 2016. 2001 marks the time when China joined the WTO and it is around the same period when China-Africa relations became more pronounced after the first ever ChinaAfrica Co-operation Forum in 2000. The period is also of significance to Zimbabwe because this is around the same period when Zimbabwe adopted the 'Look East' Policy in 2003. Therefore much of the analysis focuses on the period 2001-2016. Data used in this study is obtained from UN COMTRADE.

\section{Study Results}

This section presents and discusses the results of the various model estimations conducted to achieve the study objectives. 
INTERNATIONAL JOURNAL OF ACADEMIC RESEARCH ECONOMICS AND MANAGEMENT SCIENCES Vol. 10, No. 1, 2021, E-ISSN: 2226-3624 ㄷ 2021 HRMARS

\section{Index of Competitive Threat}

Figure 3: ICT in Zimbabwe's major export markets (2001 and 2016)

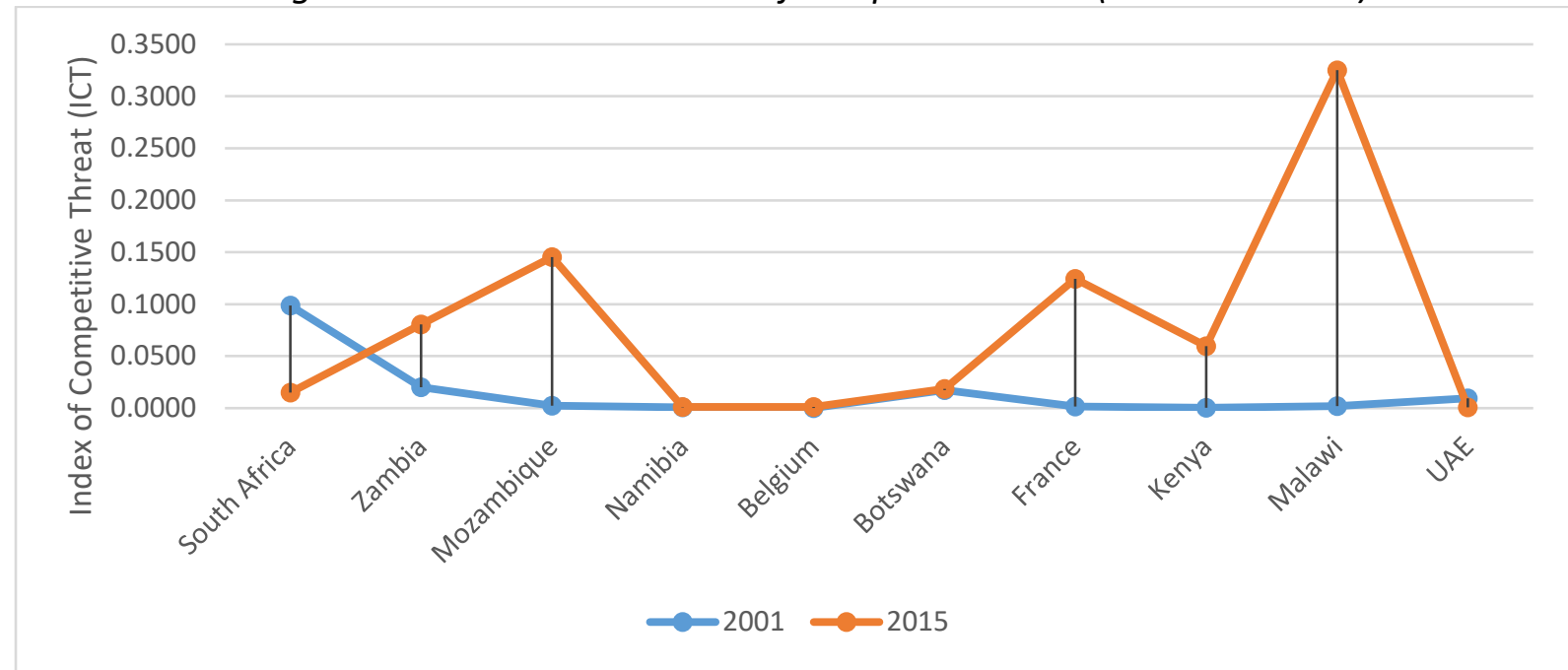

Source: Author's elaboration from UNCOMTRADE

Results shown in Figure 3 indicates that competitive threat from China in most of Zimbabwe's export markets have increased between 2001 and 2016. The markets where Zimbabwe's exports faced the greatest change in competitive threat include Malawian, Mozambican and French markets. The increase in the ICT attributed to diversification in China's production structures, which resulted in an increase in its export product coverage. The implications of the increase in ICT in Zimbabwe's major export markets especially in the Southern African region may also have implications on the region's integration efforts within the SADC, COMESA as well as under the SADC-COMESA-EAC Tripartite FTA.

\section{Constant Market Share Analysis of Zimbabwe and Chinese Exports}

The ICT has been criticised because of its failure to provide the magnitude of the impact (Jenkins, 2013). Therefore, the CMS Analysis becomes handy in such situations. Table II shows results from the CMS analysis decomposition of changes in Zimbabwe's shares of imports in the ten largest markets for Zimbabwean exports between 2001 and 2016. 
Table II: CMS Analysis of Zimbabwean exports by market, 2001-2016

\begin{tabular}{|r|l|r|r|r|r|}
\hline & $\begin{array}{c}\text { Competitiveness } \\
\text { effect (\%) }\end{array}$ & \multicolumn{1}{|c|}{$\begin{array}{c}\text { Product } \\
\text { composition } \\
\text { effect (\%) }\end{array}$} & $\begin{array}{c}\text { Relative } \\
\text { adaptation } \\
\text { effect (\%) }\end{array}$ & $\begin{array}{l}\text { Total } \\
\text { change (\%) }\end{array}$ \\
\hline 1 & South Africa & 0.12 & -0.01 & -0.04 & 0.07 \\
\hline 2 & Zambia & 0.02 & -0.01 & 0.17 & 0.18 \\
\hline 3 & Mozambique & 0.09 & 0.01 & 0.30 & 0.40 \\
\hline 4 & Namibia & -1.49 & 0.00 & 1.49 & 0.00 \\
\hline 5 & Belgium & 0.00 & 2.60 & 3.93 & 6.54 \\
\hline 6 & Botswana & 0.21 & -0.02 & -0.21 & -0.02 \\
\hline 7 & France & 0.00 & 0.00 & 0.00 & 0.00 \\
\hline 8 & Kenya & 0.06 & -0.02 & -0.06 & -0.02 \\
\hline 9 & Malawi & 3.14 & 0.02 & -3.01 & 0.14 \\
\hline 10 & UAE & -18.98 & 4.68 & 19.04 & 4.74 \\
\hline
\end{tabular}

Source: Author's elaboration from UNCOMTRADE

CMS analysis results presented in Table II reveals that Zimbabwe's competitiveness at the product level marginally increased in most of its major export markets. Zimbabwe recorded the highest improvement in competitiveness in the Malawian market (3.14 percent) whilst in other markets the competitiveness increased by less than 1 percentage point. Losses of competitiveness were experienced in the Namibian (1.49 percent) and the UAE (18.98 percent) markets whilst in France and Belgium it remained unchanged. As suggested by Fleming \& Tsiang (1956), losses of competitiveness can be attributed to some non-price factors such as differential rates of quality improvement and failure by Zimbabwean firms to invest in vibrant marketing and differential changes in the ability for prompt fulfillment of export orders. These suggested explanations are supported by findings from a study by Zimtrade, (2014) in which failure to meet international quality standards, Chinese competition, access to finance and other internal production bottlenecks were highlighted as impediments to export volumes.

CMS analysis results reveal that the initial composition of Zimbabwe exports has not significantly influenced the country's exports in most export markets. The effect was significant in Belgium and UAE whilst the Namibian and French markets, the product composition had no effect. The results from the study therefore dispels arguments by Ndlela and Tekere (2003) and COMESA (2014) that Zimbabwe's product composition has negatively affected Zimbabwe's exports to its major exports markets such as South Africa. In fact, study results are suggesting that the decline of the product structure and the current pattern of specialisation may not be a source of vulnerability for the Zimbabwean exports in most markets.

The relative adaptation effects had significant effects on the changes in Zimbabwe's market share in different markets. Results for the relative adaptation effects reflects Zimbabwe's high degree of economic integration with its regional partners especially the neighbouring countries due to 
the closeness in geographic distance. The relative adaptation effect was positive in Mozambique, Zambia, Namibia, Belgium and the UAE whilst the development of the market structure effect reveals, that the Zimbabwean foreign sector was not able to exhaust the potential of the South African, Botswana, Kenyan and Malawian markets. The relative commodity adaptation effect was zero in France implying that Zimbabwe adapted to the commodity composition at the same rate as other exporting countries.

Overall, the total effects on exports were positive in most markets between 2001 and 2016 except in Botswana and Kenya where the total effect was negative. The positive total effect in Zimbabwe's major export markets implies that Zimbabwe's exports to these markets have actually increased despite the threat posed by Chinese exports. The results from this study put to rest the fear that have been raised by Giovannetti et. al (2012); Eichegreen et.al (2004); Rhys, (2012); and Giovannetti and Sanfilippo, (2009). The gain in market share during the period under study is primarily attributable to the positive competitiveness and relative adaptation effects. This finding implies that the country took advantage of competitiveness factors to increase its market share.

\section{CMS Analysis of Chinese exports by market}

Table III shows a decomposition of the change in China's market share in Zimbabwe's top ten export markets. The results reveal negative total effect in most countries, revealing that there was a decrease in China's exports to most of Zimbabwe's major export destinations.

Table III: CMS Analysis of Chinese exports by market, 2001-2016

\begin{tabular}{|r|l|r|r|r|r|}
\hline & & $\begin{array}{l}\text { Competitive } \\
\text { effect (\%) }\end{array}$ & $\begin{array}{l}\text { Product } \\
\text { composition effect } \\
\text { (\%) }\end{array}$ & $\begin{array}{l}\text { Relative } \\
\text { adaptation effect } \\
\text { (\%) }\end{array}$ & \multicolumn{1}{l|}{$\begin{array}{l}\text { Total } \\
\text { change (\%) }\end{array}$} \\
\hline 1 & South Africa & 0.047 & -0.027 & -0.020 & 0.000 \\
\hline 2 & Zambia & 0.068 & 0.003 & 0.035 & 0.107 \\
\hline 3 & Mozambique & 0.033 & 0.000 & 3.686 & 3.719 \\
\hline 4 & Namibia & -1.054 & -12.219 & 1.055 & -12.218 \\
\hline 5 & Belgium & 0.002 & 0.009 & 0.004 & 0.014 \\
\hline 6 & Botswana & 0.040 & -0.030 & -0.028 & -0.018 \\
\hline 7 & France & 0.000 & 0.000 & 0.000 & 0.000 \\
\hline 8 & Kenya & 0.070 & -0.012 & -0.069 & -0.011 \\
\hline 9 & Malawi & 0.179 & -0.008 & -0.173 & -0.001 \\
\hline 10 & UAE & -3.123 & 3.126 & -3.116 & -3.113 \\
\hline
\end{tabular}

Source: Author's elaboration from UNCOMTRADE

Based on results shown in Table III, an increase in market share effect is observed in Zambia, Mozambique and Belgium whilst a decrease in market share is observed in Namibia, Botswana, Kenya, Malawi and the UAE. In the markets where China recorded significant changes in exports, all the three effects explained the total effect. These results are consistent with findings by Amiti and Freund's (2010). 
China recorded the greatest change in market share in Namibia, which was driven mainly by the product composition effect of $-12.21 \%$, which may imply that Chinese specialization was unfavorable to its exports to the Namibian market. The market effect contributed $1.05 \%$ implying that Namibia as a destination market has a positive influence on the Chinese exports growth. For the same Namibian market, the competitive effect negatively contributed to the total effect by $1.05 \%$. Another market where China experienced significant changes in exports was in Mozambique where the export market share increased by $3.72 \%$ with the bulk of this increase attributable to the relative adaptation effect. The competitive effect marginally affected the exports whilst the product composition effect was neutral.

Like Zimbabwe, China also experienced significant total change in exports in the UAE market where export performance decreased by $3.11 \%$. All the three effects were equally dominant although in different directions. The competitiveness and relative adaptation effects contributed negatively to China's export performance in the UAE market whilst product composition effect had a positive effect. However, the combined effect of the competitiveness and relative adaptation effects outweighed the positive product composition effect. The negative adaptation effect suggests that China lost market share relative to some faster adapting economies. It is interesting to note that for the UAE market, when China was losing market share, Zimbabwe on the other hand gained market share whilst in the Namibian market, Zimbabwe's market share remained constant implying that other countries displaced Chinese products.

\section{Zimbabwe's loss of Market Share in Manufacturing to China in Major Export Markets (2001- 2016)}

This section provides an analysis of the results from the CMS analysis on Zimbabwe's loss of market share to China in its major export markets. Table IV provides a summary of the results.

Table IV: Zimbabwe's loss of Market Share in Manufacturing to China in Major Export Markets

\begin{tabular}{|r|l|r|}
\hline & Export Market & Loss of market share (\%) \\
\hline 1 & South Africa & -1.841 \\
\hline 2 & Zambia & -2.329 \\
\hline 3 & Mozambique & -0.184 \\
\hline 4 & Namibia & -0.090 \\
\hline 5 & Belgium & 0.003 \\
\hline 6 & Botswana & -0.122 \\
\hline 7 & France & 0.105 \\
\hline 8 & Kenya & -0.025 \\
\hline 9 & Malawi & 0.011 \\
\hline 10 & UAE & -0.706 \\
\hline
\end{tabular}

Source: Author's elaboration from UNCOMTRADE

Results presented in Table IV shows that Zimbabwe experienced market share losses in most export markets for its manufactured exports to Chinese exports. Losses to China were experienced in South Africa (1.8 percent), Zambia (2.33 percent), UAE (0.71 percent) and 
Mozambique (0.18 percent) whilst market share gains were recorded in Belgium, France and Malawi. The market share gains in Belgium and France can be linked to the duty free market access under the interim Economic Partnership Agreement for Zimbabwe's products where Chinese products face MFN duties. The results from this study contradicts findings from a study by Husted \& Nishioka (2013) which found out that the growth in Chinese export market share came largely at the expense of exporters in developed countries, in particular Japan and the United States, rather than exporters from developing countries. The results are also not consistent with findings by Hanson and Robertson (2010) who did not find any evidence of loss of market share by developing countries during the same period despite China's export growth.

\section{Loss of Market share by product}

Study results shows that products greatly affected by Chinese competition are mainly from the labour intensive sectors that include agriculture, clothing and textiles and light manufacturing. The loss in market share by Zimbabwe to China in some markets such as South Africa in iron and steel products may be attributed to the closure of ZISCO Steel that has not been operational for a long period resulting in the remaining companies in the iron and steel industries being less competitive. Table $\mathrm{V}$ shows the leading products in terms of loss of market share to China.

Table V: Leading products in terms of loss of Market Share to China (2001-2016)

\begin{tabular}{|c|c|c|}
\hline Market & HS Code & Product Description \\
\hline \multirow[t]{2}{*}{ South Africa } & '840734 & $\begin{array}{l}\text { Spark-ignition reciprocating piston engine, of a kind used for } \\
\text { vehicles of chapter } 87 \text {, }\end{array}$ \\
\hline & $' 731700$ & Nails, pins, corrugated nails, and similar articles of iron or steel, ... \\
\hline \multirow{2}{*}{ Zambia } & '680291 & Marble, travertine and alabaster \\
\hline & '551311 & Plain woven fabrics \\
\hline \multirow{2}{*}{ Mozambique } & '360690 & Ferro-cerium and other pyrophoric alloys. \\
\hline & '030471 & Frozen fillets of cod. \\
\hline \multirow{2}{*}{ Namibia } & '681011 & Building blocks and bricks of cement, concrete or artificial stone. \\
\hline & '020442 & Frozen cuts of sheep, (excluding carcases and half-carcases) \\
\hline \multirow[t]{2}{*}{ UAE } & '890190 & $\begin{array}{l}\text { Vessels for the transport of goods and vessels for the transport of } \\
\text { both persons and goods... }\end{array}$ \\
\hline & '720712 & Semi-finished products of iron or non-alloy steel \\
\hline \multirow{2}{*}{ Belgium } & '284920 & Carbides of silicon.... \\
\hline & '030363 & Frozen cod.... \\
\hline \multirow[b]{2}{*}{ Botswana } & '930110 & Artillery weapons..... \\
\hline & '730451 & $\begin{array}{l}\text { Tubes, pipes and hollow profiles, seamless, of circular cross-section, } \\
\text { of alloy steel other ... }\end{array}$ \\
\hline \multirow{2}{*}{ France } & $' 722720$ & Bars and rods of silico-manganese steel.... \\
\hline & ' 851420 & Furnaces and ovens.... \\
\hline
\end{tabular}


INTERNATIONAL JOURNAL OF ACADEMIC RESEARCH ECONOMICS AND MANAGEMENT SCIENCES Vol. 10, No. 1, 2021, E-ISSN: 2226-3624 @ 2021 HRMARS

\begin{tabular}{|l|l|l|}
\multirow{4}{*}{ Kenya } & '480449 & Kraft paper and paperboard, uncoated, in rolls of a width $>36 \mathrm{~cm}$ \\
\cline { 2 - 3 } & '382478 & Mixtures containing perfluorocarbons "PFCs" \\
\hline \multirow{3}{*}{ Malawi } & '611020 & $\begin{array}{l}\text { Jerseys, pullovers, cardigans, waistcoats and similar articles, of } \\
\text { cotton, knitted or crocheted ... }\end{array}$ \\
\cline { 2 - 3 } & '940421 & Mattresses of cellular rubber or plastics, whether or not covered \\
\hline
\end{tabular}

Source: Author's elaboration from UNCOMTRADE

From the results presented in Table $\mathrm{V}$, it is disappointing to note that in markets such Mozambique, Namibia, Belgium and Malawi products with a link to the agricultural sectors are among the products displaced by Chinese exports. This raises concern over the effect of Chinese competition on the Zimbabwean economy considering that the agriculture sector is very important to the economy in terms of its contribution to GDP and employment creation. This loss in market share in sectors linked to the agricultural sector will likely result in severe economic effects for Zimbabwe because of the backward and forward linkages that the agricultural sector has with other sectors such as manufacturing. Overall, the results indicate that Zimbabwe lost export market share to China mainly in labour intensive sectors that are key to Zimbabwe in terms of employment.

\section{Policy Implications}

Study results from the CMSA have revealed that Zimbabwean firms have lost market share in some of its traditional export market because of both price and non-price competitiveness factors. It is therefore recommended that in order to address the price competitiveness issues that affect its market share, exporters need to be supported in their production and marketing processes to further improve their performance in world markets. A possible entry point into the production chain aimed at lowering production costs would be to come up with an export incentive system aimed at reviving the manufacture of export products.

Consequently, the main results of our CMS analysis indicate that in almost 40 per cent of the export markets analysed, the product composition negatively contributed to the change in Zimbabwe's export performance. This finding calls for policies that aim at improving the commodity composition of Zimbabwe's exports through product diversification to meet the demand of new alternative markets.

The study results also reveal significant market share losses by Zimbabwe to China in Zimbabwe's low tech and traditional exports products despite the increasing sophistication of Chinese exports. It is therefore recommended that Zimbabwe move up the ladder in terms of export structure through upgrading its industry to enable its exports to compete at the highest level of that ladder. This can be done through the adoption and reinforcement of policies that encourage the export of finished manufactured goods and heavily refined and processed products. The country can also embark on qualitative upgrading of its exports so that it can at least offset part of the competitive pressure coming from China. In addition, Zimbabwe should shift the focus of 
its policy-setting attention from merely expanding the scale of its export trade to enhancing its efficiency.

\section{Conclusions}

This study focused on the impact of Chinese competition on Zimbabwe's exports in third markets. Study results showed that Zimbabwe's export performance in its major export markets increased except in Botswana and Kenya whilst the exports to France remained constant. When the results of the CMS analysis are considered, the most dominant effects that contribute positively to Zimbabwe's export performance in most export markets is the relative adaptation effect whilst in the UAE and Malawi, the competitiveness effect substantially contributed to the increase in export performance. Based on the study findings, we therefore failed to reject the study hypothesis that Chinese exports displaces Zimbabwe's exports in third markets. The overlap in Zimbabwe's exports with those exported by China is confirmed by the study results that have provided evidence of displacement of Zimbabwe's export products belonging to various sectors of the economy. This is true for the cases of textiles and clothing (Malawi and Zambia) and other products related to Zimbabwe's traditional sectors of specialisation such as agriculture related products.

This study investigated the competitive effects of Chinese products on Zimbabwe's exports of manufactured products in third markets using Constant Market Share Analysis. This is the first study focussing on Zimbabwe that have used the Constant Market Share Analysis alongside index of competitive threat to assess the impact of Chinese exports on Zimbabwe's exports in third markets. In general, no study has attempted to use CMS approach to assess Zimbabwe's export performance in third markets. Furthermore, CMS analysis will decompose the export performance into three components: market share effect or competitiveness effect, commodity or product composition effect, and the relative commodity adaptation effect. This decomposition will make it easier to identify the country's export performance attributed to competiveness and the performance attributable to product composition of exports, which are critical for trade policy formulation.

\section{References}

Adams, F. G., Gangnes, B., \& Shachmurove, Y. (2006). Why is China so competitive? Measuring and explaining China's competitiveness. The World Economy, 29(2), 95-122. https://doi.org/10.1111/j.1467-9701.2006.00773.x

Ademola, O. T., Bankole, A. S., \& Adewuyi, A. O. (2009). China-Africa trade relations: Insights from AERC scoping studies. European Journal of Development Research, 21(4), 485-505. https://doi.org/10.1057/ejdr.2009.28

Ado, A., Su, Z., Ado, A., \& Su, Z. (2016). China in Africa: a critical literature review. https://doi.org/10.1108/cpoib-05-2013-0014

Ajakaiye, O. (2006). China and Africa - Opportunities and Challenges. African Union Task Force on Strategic Partnership Between Africa and the Emerging Countries of the South Addis Ababa, Ethiopia, 11-13 September 2006, September, 1-14. http://www.africaportal.org/dspace/articles/china-and-africa---opportunities-andchallenges 
Batista, J. C. (2006). A New Extended Constant Market Share Model. 1951.

Chen, K. Z., Duan, Y., \& Chen, K. Z. (2001). Competitiveness of Canadian Agri-Food Exports Against Competitors in Asia Competitiveness of Canadian Agri-Food Exports Against Competitors in Asia : 1980-97. 4438. https://doi.org/10.1300/J047v11n04

COMESA. (2014). Impact Assessment of Concluding an EPA with EU on Zimbabwe's Economy, COMESA Secretariat, Lusaka, Zambia.

Eichengreen, B., Rhee, Y., \& Tong, H. (2004). THE IMPACT OF CHINA ON THE EXPORTS OF OTHER ASIAN COUNTRIES. In NBER WORKING PAPER SERIES (Vol. 39, Issue Working Paper 10768). http://search.ebscohost.com/login.aspx?direct=true \&db=poh\&AN=89040178\&site=ehostlive

Fagerberg, J., \& Sollie, G. (1987). The method of constant market shares analysis reconsidered. Applied Economics, 19(12), 1571-1583. https://doi.org/10.1080/00036848700000084

Fleming, A. J. M., \& Tsiang, S. C. (1956). Changes in Competitive Strength and Export Shares of Major Industrial Countries Changes in Competitive Strength and Export Shares of Major Industrial Countries. 5(2), 218-248.

Geda, A., \& Meskel, A. G. (2008). China and India's growth surge: Is it a curse or blessing for Africa? The case of manufactured exports. African Development Review, 20(2), 247-272. https://doi.org/10.1111/j.1467-8268.2008.00184.x

Giovannetti, G., \& Sanfilippo, M. (2009). Do Chinese exports crowd-out African goods? An econometric analysis by country and sector. European Journal of Development Research, 21(4), 506-530. https://doi.org/10.1057/ejdr.2009.20

Giovannetti, G., Sanfilippo, M., \& Velucchi, M. (2010). The "China effect " on Italian Exports. November, 1-18.

Giovannetti, G., \& Sanfilippo, M. (2009). Do Chinese Exports Crowd-Out African Goods ? An econometric analysis by country and sector. 1-21.

Greenaway, D., Mahabir, A., \& Milner, C. (2008). Has China displaced other Asian countries' exports? China Economic Review, 19(2), 152-169.

https://doi.org/10.1016/j.chieco.2007.11.002

Hanson, G., \& Robertson, R. (2010). China and the manufacturing exports of other developing countries. In R. Feenstra \& S.-J. Wei (Eds.), China's growing role in world trade. Cambridge: National Bureau of Economic Research.

Husted, S., \& Nishioka, S. (2013). China's fare share? The growth of Chinese exports in world trade. Review of World Economics, 149(3), 565-585. https://doi.org/10.1007/s10290-0130149-2

Jenkins, R. (2012). China and Brazil : Economic Impacts of a Growing Relationship.

Jenkins, R., \& Edwards, C. (2006). The Asian drivers and sub-Saharan Africa. IDS Bulletin, 37(1), 23-32. https://doi.org/10.1111/j.1759-5436.2006.tb00244.x

Jenkins, R., \& Edwards, L. (2013). IS CHINA " CROWDING OUT" SOUTH AFRICAN EXPORTS OF MANUFACTURES *. 1-26.

International Monetary Fund (IMF) (2004). World Economic Outlook April 2006. Washington DC: International Monetary Fund.

Kaplinsky, R., Mccormick, D., \& Morris, M. (n.d.). China and Sub Saharan Africa: Impacts and Challenges of a Growing Relationship.

Lall, S., \& Albaladejo, M. (2004). China's competitive performance: A threat to East Asian 
INTERNATIONAL JOURNAL OF ACADEMIC RESEARCH ECONOMICS AND MANAGEMENT SCIENCES

Vol. 10, No. 1, 2021, E-ISSN: 2226-3624 C 2021 HRMARS

manufactured exports? World Development, 32(9), 1441-1466. https://doi.org/10.1016/j.worlddev.2004.03.006

Lin, J. Y., \& Wang, Y. (2014). WIDER Working Paper 2014/046 China-Africa co-operation in structural transformation: Ideas, opportunities, and finances - WP2014-046.pdf (Issue February). http://www.wider.unu.edu/stc/repec/pdfs/wp2014/WP2014-046.pdf

Ndlela, D., and Tekere, M. (2003) Impact Assessment of Economic Partnership Agreements on Southern African Development Community and Preliminary Adjustment Scenarios. Harare, Zimbabwe: Trade and Development Studies Centre.

Qureshi, M. S., \& Wan, G. (2006). Trade Potential of China and India: Threat or Opportunity? + Mahvash Saeed Qureshi. 1-28.

Razmi, A., \& Blecker, R. A. (2006). Developing Country Exports of Manufactures: Moving Up the Ladder to Escape the Fallacy of Composition? (Issue April).

Schiere, R., Ndikumana, L., \& Walkenhorst, P. (2011). China and Africa: An emerging partnership for development? In African Development Bank Group (Issue May).

Sekakela, K. (2014). BIDPA Working Paper 40 (Issue September).

Song, L., Li, K. (2005). China's trade expansion and the Asia Pacific economies. The China Boom and Its Discontents. https://doi.org/10.1515/9783110800487.39

Stevens, C., \& Kennan, J. (2006). How to Identify the Trade Impact of China on Small Countries. $37(1), 33-42$.

Yang, T. Z., and D. V. (2000). The Fallacy of Composition and the Terms of Trade of Newly Industrializing Economies. Review of World Economics, 143(2), 201-226. https://doi.org/10.1007/s10290-007-0105-0

Zimtrade. (2014).Final_Export_Capacity_Survey_Report_2013-12-19_(1)[1].ZIMTRADE. 